\title{
Professional Development in Science Summer Schools: How Science Motivation and Technology Interest Link in with Innovative Educational Pathways
}

\author{
Marth Michaela and Bogner Franz X. \\ University of Bayreuth \\ ZMNU (Centre of Math \& Science Education), \\ Department of Biology Education, Germany \\ Sotiriou Sofoklis \\ Ellinogermaniki Agogi \\ R\&D Department, Pallini, Athens, Greece
}

\begin{abstract}
Our empirical study monitored science teachers' motivation and technology interest within a Professional Development (PD) module in a science summer school. The first empirical measurement consisted of the Science Motivation Questionnaire (SMQ) and the second of the Technology Questionnaire (TQ). A pre-/postmeasurement recorded very high motivation and interest scores even before participation, which in a kind of ceiling effect might have caused the monitored stagnation in motivation and interest. However, science motivation and technology interest showed a close relationship, while no gender difference appeared in both scales. The inquiry-based science education (IBSE) strategy is regarded one brick to enrich teachers' daily classroom life, as $65.8 \%$ of the participating teachers had used IBSE already before, while after participation $60.5 \%$ of them intended to even further increase its application in their classrooms. Within that context, motivation is regarded as one of the major positive features of IBSE to bring new life into classrooms.
\end{abstract}

Keywords summer school; professional development (PD); science motivation; technology interest; IBSE

\section{Introduction}

Although science nowadays is incorporated in our daily routine (Ardies, De Maeyer, Gijbels, \& van Keulen, 2015), too few students choose careers in STEM (science, technology, engineering, math) (Dabney et al. 2012). Teaching science and improving scientific literacy are major goals for preparing our young children for life after school (DeBoer, 2000). The ultimate target intends to direct 
as many as possible young people to scientific literate individuals with feeling more competence within technology and science (Laugksch, 2000). "Literate" is understood with two meanings, on the one hand learning and on the other hand reading and writing (Miller, 1983). School curricula nowadays arrange the field to appropriately prepare for later careers (ISB, 2004). Science education in its major aim is supporting scientific literacy in school as teachers act as "vehicles" to transfer intrinsic motivation to students' mind. For students, summer camps outside of school time provide a great possibility to raise interest and motivation towards science as well as to influence later-on career choices (Gibson \& Chase, 2002). Summer science-enrichment programs often show a splashdown effect, which means that program sustains effects later at home (Stake \&Mares, 2005). However, also teachers may need to enhance their knowledge and motivation as Sterling, Matkins and Frazier (2007) has shown for problem-based learning in scientific context. Out-of-school time science activities like summer camps could offer a possibility to raise motivation and to alert more students to the science sector (Dabney et al., 2012). Consequently, many universities have established outreach summer programs for precollege students and in-service teachers to strengthen the science sectors, to let them participate on the real work of scientists as well as to acquire new skills (Markowitz, 2004). As teachers have to motivate and promote science, self-motivation is the trigger to motivate students, too (Knox, Moynihan, \& Markowitz, 2003).

Definition of motivation has produced over 100 different descriptions during the last 35 years (Kleinginna \& Kleinginna, 1981). When allocating all of them into categories: the first covers internal mechanisms, the second dealt with functional processes, the third confined the limit of motivation but also accentuated the broad character of motivation. Motivation often is associated with self-efficacy, control belief and self-responsibility (Pintrich \& De Groot, 1990). Science motivation is defined as 'an internal state that arouses, directs, and sustains science-learning behavior' (Glynn, Brickman, Armstrong, \& Taasoobshirazi, 2011a). This is for students, educators as well as in-service teachers the main source of interest and motivation for science. Therefore, facilitating motivation and introducing new interest into classrooms seem to provide a big issue of improvement. For designing educational programs knowledge of pre-existing levels of science motivation may act as a good predictor of success of such interventions. For observation of science motivation, Glynn, Taasoobshirazi, \& Brickman (2009) developed a 30-item Science Motivation Questionnaire (SMQ), which was originally designed for college students to measure the science motivation. A later modification contained five subscales: intrinsic motivation (IM), self-efficacy (SE), self-determination (SD), career motivation (CM) and grade motivation (GM). Schumm \& Bogner (2016) applied the SMQ-II to high school students as well as Schmid \& Bogner, (2015) did. The latter used three sub-scales for monitoring an inquiry approach of an interdisciplinary lessonunit. Similarly, Marth \& Bogner (2017) applied the scale to lower secondary school students.

Technology is regarded another important activator for science, its education and is nearly everywhere in our daily life apparent (Ardies et al., 2015). As the 
young generation grows up in a technology world, technology is commonplace like in social media and communication technology ( $\mathrm{O}^{\prime}$ Keeffe \& Clarke-Pearson, 2011). The society is actually dependent on technology, because nearly nothing works without technology know-how (Bouras \& Albe, 2008). However, the interest and attitudes towards technology apparently are decreasing within a school career associating technology with boredom and learning difficulties (Ardies, De Maeyer, \& David Gijbels, 2013) and teachers are the major triggers to chance this.

Science and technology often produce gender differences. Marth \& Bogner (2018) for example showed gender differences for school students, freshmen and teachers in technology interest and social aspects of technology: Male participants showed more technology interest and social aspects of technology. Only the subscale of social aspects in the teachers' cohort showed no gender difference. This trend is often visible in the science sector, as it traditionally is regarded a male-dominated field, where women often feel discriminated and choose other sectors like education or social sectors (Steele, James, \& Barnett, 2002). Women also have mostly to combine family and career, so that their male colleagues often have better conditions (Frome, Alfeld, Eccles, \& Barber, 2006). Women choosing a science career show often less academic self-concept (ÜlküSteiner, Kurtz-Costes, \& Kinlaw, 2000).

A possibility to overcome the gender gap and the frequent drop in science and technology motivation might provide the method of inquiry-learning. In the constructivism view, knowledge couldn't be transferred from one person to another; knowledge needs individual integration and an active thinking process (Cakir, 2008). In such a constructivist approach of learning students need to create concepts with scientific experiences (Tamir, 1985). Thus inquiry-based teaching and learning get more and more attention in science education (Osborne \& Dillon, 2008; Rocard et al., 2007). The advantages of inquiry-based science education (IBSE) have often been approved (Russ, Scherr, Hammer, \& Mikeska, 2008; Minner, Levy, \& Century, 2010). A frequent approach builds upon reduction of content knowledge (Mishra \& Koehler, 2006). Acknowledging the different levels of autonomy of students, in general four levels of inquiry are followed up: Level-0/verification, level-1/structured, level-2/guided and level3/open (Blanchard et al. 2010); adapted from Schwab \& Brandwein (1962) and Colburn (2000). The more autonomy, the higher the level in IBSE is: In level-0, nearly everything is decided by the teacher, for example, the method, the questions and the interpretation of the results. In level 1 , the interpretation is made by students. In level 2, students get some more responsibility for the methods and the interpretation. In level 3, in the contrary nearly everything is decided by students. Thus, a teacher needs to know the different levels in order to use it adequately.

The objectives of our study were: (I) analyzing the motivational and interest level of summer school participating in-service teachers, (II) analyzing the influence of a summer school to science motivation and technology interest, (III) examining the relationship between science motivation and technology interest, 
(IV) analyzing gender differences, and (V) analyzing what's IBSE for teachers and how they use it.

\section{Methods}

Participants

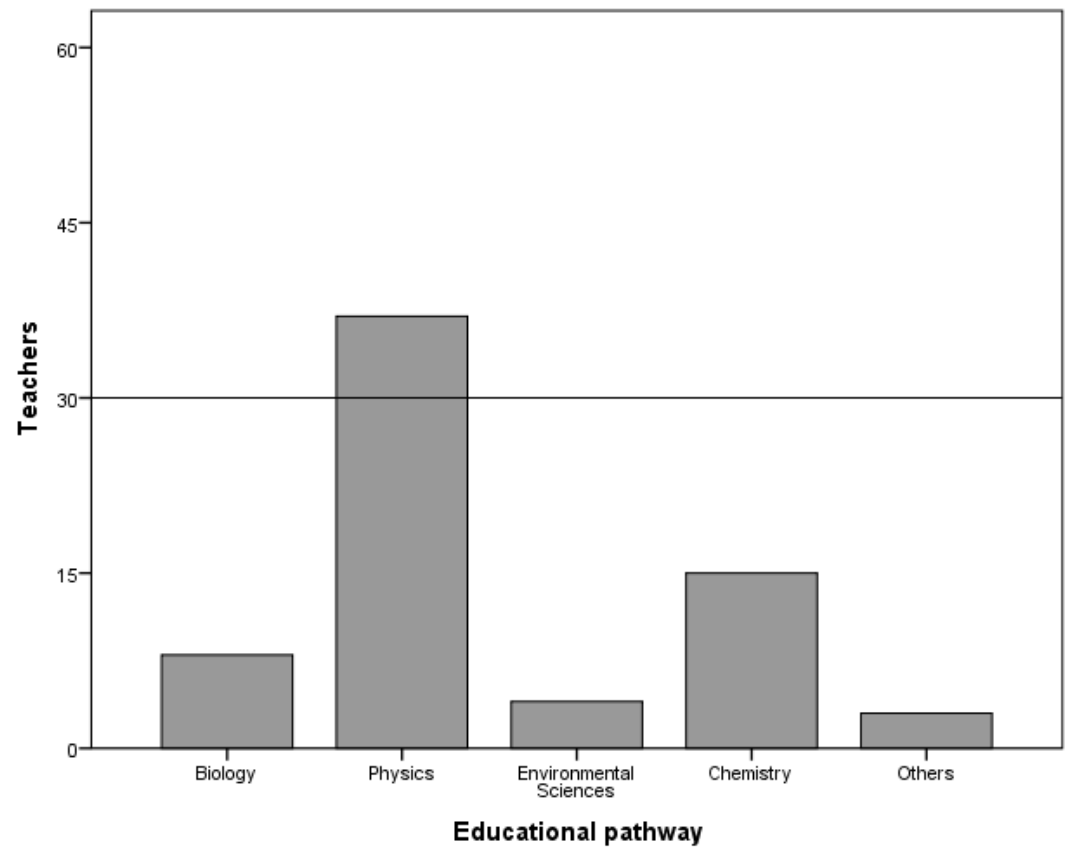

Figure 1: Educational background of the participating teachers

Subjects were science teachers from Europe and the US $(M=43.15$ years; $S D=9$. 43) teaching in Physics (37), Chemistry (15), followed by Biology (8) and Environmental Education (4) and some of them have other specialized subjects (3) like Geoscience (see Figure 1). The gender was balanced (46.3\% women (31); $53.7 \%$ men (36) (see Figure 1). All teachers participated in a week-long summer school in Greece.

\section{CREATIONS summer school}

The summer school supported a "dialogue" between science and education by enforcing a collaboration between schools and research organizations in using label: catalyst. Teachers worked in groups, exchanged ideas and learned new teaching methods, in specific how to enrich with the element of creativity. Furthermore, starting to establish and to strengthen network building for teachers who participating the summer school. The main objective was to introduce innovative approaches and activities that are based on Arts (from STEM to STEAM). A further focus laid on the development of effective links and synergies between schools and research infrastructures in order to spark young people's interest in science and in following scientific careers. 
Inspiring Science (ISE) summer school

Educational pathways were offered by cooperating with experts and science centers. One major example was the offer to cooperate with CERN (Conseil européen pour la recherche nucléaire = European Organization for Nuclear Research), the world famous scientific research center in Geneve/Switzerland. Our teacher participated in a virtual visit of CERN by learning about scientific problems, and of course solving inquiry-based related problems. Teachers worked with the inspiring science educational portal and learned about the advantage of combing classroom with robotic telescopes. The aim was to provide new learning resources and possibilities for teachers to make science more attractive for students and their lives.

Both summer schools aimed to improve the science teaching process through new methods and approaches like IBSE (Blanchard et al., 2010). As teachers play an important role in forming children's attitudes in science and technology, enriching teacher's experiences is of great importance (Feldman, 1976). Summer schools could be a stimulation to use more and new approaches to teaching, as well as the acquiring of new knowledge (Ernest, 1989).

\section{Instruments}

We applied the technology questionnaire modified by Marth \& Bogner (2017). The main domain: "What do you think about technology?" contained two subscales: "interest in technology" and "social aspects of technology". Every subscale consisted of 5 items following a five-point Likert scale response pattern. For the Science Motivation, we applied the scale of Glynn, Brickman, Armstrong, \& Taasoobshirazi (2011), containing five sub-scales (intrinsic motivation, self-efficacy, self-determination, grade motivation, career motivation) with every 5 items, again with a five-point Likert scale response pattern. Both questionnaires were completed at two testing points, before and after participating in the summer school.

\section{Statistical analysis}

Statistical analysis was conducted using SPSS Version 23. We analyzed the SMQ sub-scales and the TQ sub-scales using the mean scores. For the comparison, if there is a difference before and after the summer school we used paired t-test for each sub-scale. Moreover, gender differences were analyzed for the SMQ and the TQ. The Pearson correlation coefficient shows the relationship of SMQ among each other, between SMQ and the TQ and the TQ sub-scales one below the other. Another Pearson correlation between the SMQ-II, TQ and the subject specification shows the relation between those variables. Additionally some multiple-choice questions about IBSE were used. Three questions were to answer with yes or no, out of that we calculate the percent of the answer possibilities. The participants got two more questions with each 5 answer possibilities, where they could mark with a cross the "in their view" right ones. The maximum of each answer possibility is 67 . 


\section{Results}

The Kolmogorow-Smirnow test showed a normal distributed sample solution $\mathrm{D}(49)=.073, \mathrm{p}=.200$, that is why we applied parametric testing methods. The overall reliability of the sample showed reasonable results $(\alpha=.925)$. We used all five sub-scales of the SMQ-II (career Motivation $=\mathrm{CM}$, self-efficacy $=\mathrm{SE}$, selfdetermination $=\mathrm{SD}$, grade motivation $=\mathrm{GM}$ and intrinsic motivation=IM) to show the science motivation of the participating teachers. Additionally, we used the TQ for detecting the interest in technology and the social aspects of technology of the teachers, who are participating in the summer schools. In Figure 2, where the mean scores of the sub-scales of SMQ II a TQ at testing point T0 are shown.

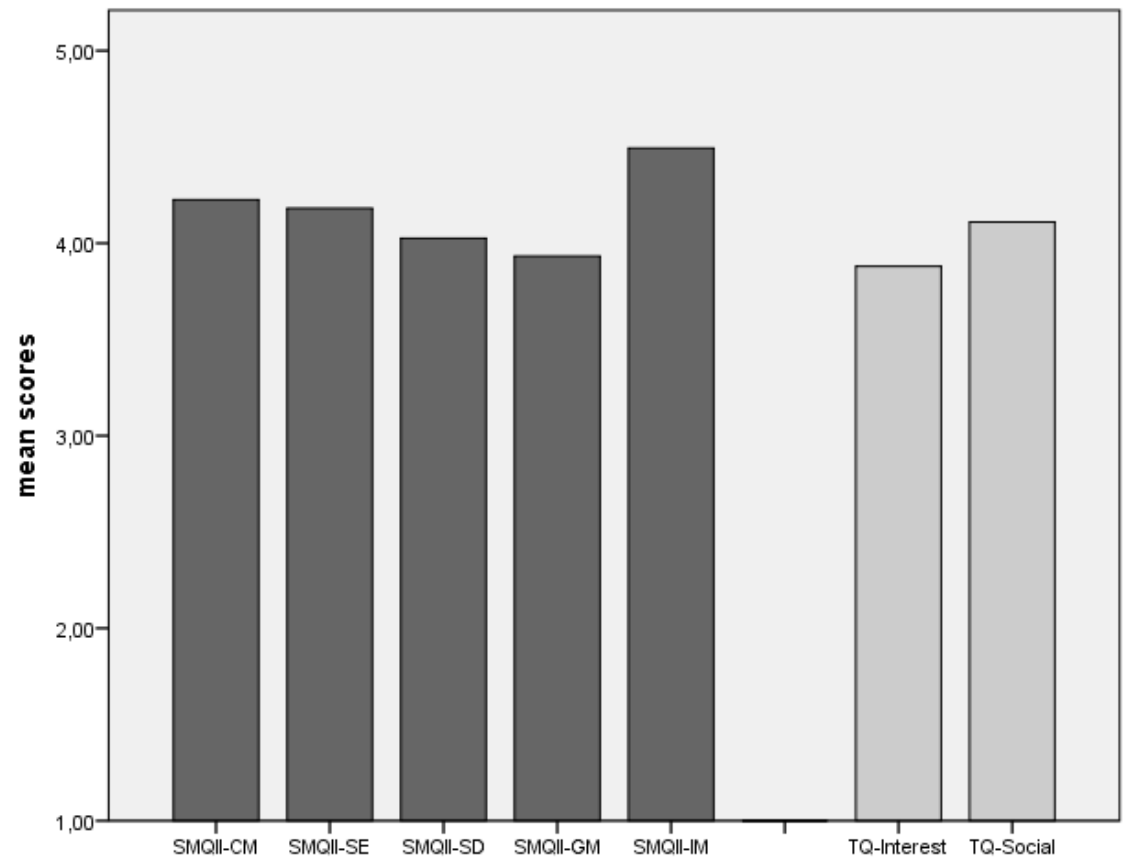

Figure 2: Mean scores of the SMQ sub-scales and the TQ sub-scales at testing point T0.

Table 1: T-Tests sub-scales SMQ-II at testing points: T0 and T1.

\begin{tabular}{cccccccc}
\hline & \multicolumn{3}{c}{ SMQ II } & & \multicolumn{2}{c}{ TQ } \\
\cline { 2 - 8 } & IM & CM & GM & SE & SD & Interest & Social \\
\hline T0 & 4.494 & 4,225 & 3.933 & 4,182 & 4,026 & 3,883 & 4,110 \\
$(\mathbf{M} \pm \mathbf{S})$ & \pm .471 & \pm .615 & \pm .656 & \pm .550 &, \pm 650 & \pm .691 & \pm .610 \\
\hline T1 & 4.491 & 4,215 & 3.920 & 4.179 & 4,056 & 3.888 & 4,125 \\
$(\mathbf{M} \pm \mathbf{S})$ & \pm .716 & \pm .685 & \pm 811 & \pm .693 & \pm .662 & \pm .733 & \pm .551 \\
\hline T-Test & $\mathrm{t}(51)=.020 ;$ & $\mathrm{t}(52)=.153 ;$ & $\mathrm{t}(44)=.167 ;$ & $\mathrm{t}(45)=.047 ;$ & $\mathrm{t}(48)=-.449$ & $\mathrm{t}(52)=.087 ;$ & $\mathrm{t}(55)=.259 ;$ \\
T0-T1 & $\mathrm{p}=.984$ & $\mathrm{p}=.879$ & $\mathrm{p}=.868$ & $\mathrm{p}=.963$ & $\mathrm{p}=.656$ & $\mathrm{p} .=931$ & $\mathrm{p}=.796$ \\
& n.s. & n.s. & n.s. & n.s. & n.s. & n.s. & n.s
\end{tabular}

The motivation sub-scales scored very high from 3,93 to 4.49; the single scores and the standard deviation are shown in Table 1. The technology questionnaire 
(TQ), too, scored very high from 3.88 to 4.11; single scores and standard deviation are also shown in Table 1. Motivation and technology preferences were monitored also after participating in the summer school, the scores are shown in Table 1 . We have compared the mean scores by using t-tests to extract the impact of summer schools. Compared to the testing point T0, participating in our summer school did not produce an effect at T1 (see Table 1). No t-tests signaled significance.

Table 2: Correlation of motivation and technology sub-scales

\begin{tabular}{lllllllll}
\hline & \multicolumn{9}{c}{ SMQ Sub-Scales } & & \multicolumn{3}{c}{ TQ } \\
\cline { 3 - 9 } & & IM & CM & GM & SE & SD & Interest & Social \\
\hline IM & Sig. & & $.010^{*}$ & $.036^{*}$ & $.004^{*}$ & $.000^{* *}$ & .284 & $.036^{*}$ \\
& Cor. & 1 & .326 & .294 & .386 & .630 & & .265 \\
\hline CM & Sig. & $.010^{*}$ & & $.001^{* *}$ & $.000^{* *}$ & $.000^{* *}$ & $.033^{*}$ & .255 \\
& Cor. & .326 & 1 & .440 & .499 & .446 & .269 & \\
\hline GM & Sig. & $.036^{*}$ & $.001^{* *}$ & & $.006^{*}$ & $.001^{* *}$ & .611 & .987 \\
& Cor. & .294 & .440 & 1 & .375 & .454 & & \\
\hline SE & Sig. & $.004^{*}$ & $.000^{* *}$ & $.006^{*}$ & & $.000^{* *}$ & $.035^{*}$ & $.016^{*}$ \\
& Cor. & .386 & .499 & .375 & 1 & .683 & .281 & .318 \\
\hline \multirow{2}{*}{ SD } & Sig. & $.000^{* *}$ & $.000^{* *}$ & $.001^{* *}$ & $.000^{* *}$ & & $.019^{*}$ & $.001^{* *}$ \\
& Cor. & .630 & .446 & .454 & .683 & 1 & .302 & .402 \\
\hline Interest & Sig. & .284 & $.033^{*}$ & .611 & $.035^{*}$ & $.019^{*}$ & & $.000^{* *}$ \\
& Cor. & & .269 & & .281 & .302 & 1 & .728 \\
\hline Social & Sig. & $.036^{*}$ & .255 & .987 & $.016^{*}$ & $.001^{* *}$ & $.000^{* *}$ & \\
& Cor. & .265 & & & .318 & .402 & .728 & 1 \\
\hline
\end{tabular}

Correlation between SMQ-II and TQ

Pearson correlation extracted some positive relationship between motivation (SMQ) and technology preferences (TQ) (see Table 2). All motivation sub-scales showed significant effects with each other. The same is true for technology preference subscales. However, the relationship between motivation and technology preferences was small, but existing. The interest sub-scale showed positive correlations' with career-motivation, self-efficacy, and selfdetermination (SMQ). The TQ's social sub-scale showed also positive correlations with the motivation sub-scales intrinsic motivation, self-efficacy and self-determination. Finally, gender did not produce significant differences (see Table 3). Male and female teachers have no disparity in science motivation and technology interest. 
Table 3: SMQ, TQ from female and male participants.

\begin{tabular}{|c|c|c|c|c|c|c|c|}
\hline & \multicolumn{5}{|l|}{ SMQ II } & \multicolumn{2}{|l|}{ TQ } \\
\hline & IM & CM & GM & SE & SD & Interest & Social \\
\hline \multirow{2}{*}{$\begin{array}{l}\text { Female } \\
(\mathrm{M} \pm \mathrm{SD})\end{array}$} & 4.537 & 4.187 & 3.969 & 4,030 & 3.902 & 3,684 & 3.987 \\
\hline & \pm .446 & \pm .607 & \pm .538 & \pm .501 &, \pm 629 & \pm .675 & \pm .651 \\
\hline \multirow{2}{*}{$\begin{array}{l}\text { Male } \\
(\mathrm{M} \pm S D)\end{array}$} & 4.442 & 4,264 & 3.767 & 4.199 & 4,094 & 4.000 & 4,159 \\
\hline &. \pm .487 & \pm .676 & \pm .864 & \pm .669 & \pm .641 & \pm .680 & \pm .569 \\
\hline T-Test & $\mathrm{t}(61)=.79$ & $t(61)=-$ & $\mathrm{t}(51)=.982 ;$ & $t(55)=-$ & $t(58)=-$ & $t(62)=-$ & $t(63)=$ \\
\hline \multirow[t]{3}{*}{ T0-T1 } & 9 & .474 & $\mathrm{p}=.331$ & 1.054; & 1.168 & 1.865; & 1.134; \\
\hline & $\mathrm{p}=.428$ & $p=.637$ & n.s. & $p=.296$ & $\mathrm{p}=.247$ & p. $=.067$ & $p=.261$ \\
\hline & n.s. & n.s. & & n.s. & n.s. & n.s. & n.s \\
\hline
\end{tabular}

Table 4: Correlation subject specification, SMQ and TQ sub-scales.

\begin{tabular}{llllccccc}
\hline & & \multicolumn{4}{c}{ SMQ } & \multicolumn{2}{c}{ TQ } \\
& & IM & CM & GM & SE & SD & Interest & Social \\
\hline \multirow{2}{*}{ Subject } & Sig. & .492 & .390 & .403 & .988 & .099 & $.012^{*}$ & .230 \\
& Cor. & & & & & & .334 & \\
\hline
\end{tabular}

The correlation between the subject specification, the SMQ, and the TQ showed only one significant correlation between interest in technology and the science specification (see Table 4).

IBSE and digital resources approach

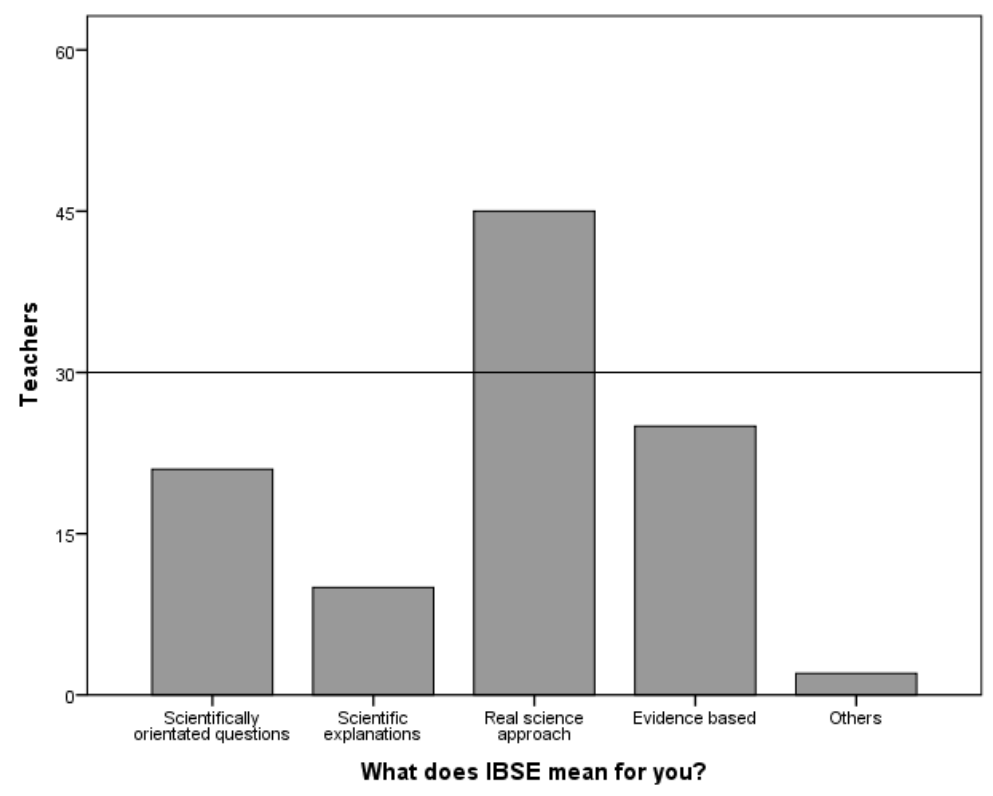

Figure 3: Teachers answers what they understand under IBSE. 


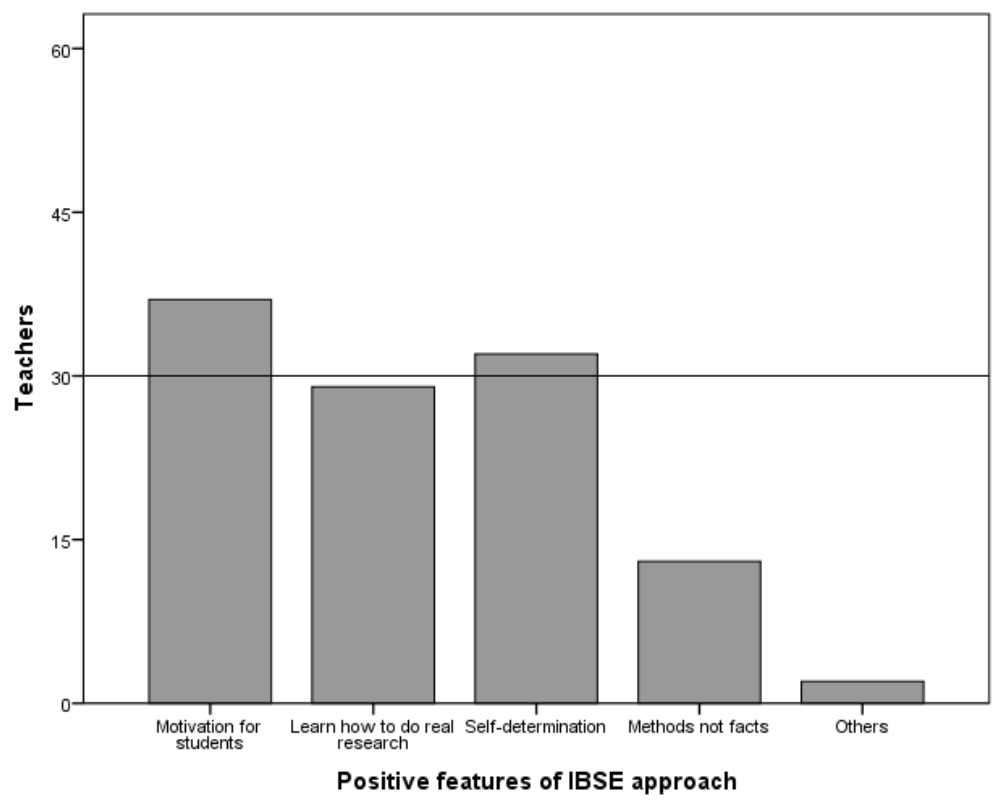

Figure 4: Teachers answers what are positive features of IBSE.

The three questions about IBSE showed that $65.8 \%$ have used IBSE approach even before the summer school, but the summer school had motivated $60.5 \%$ to use it more after participating in the summer school. In general, 91.0\% judged IBSE as meaningful in science education. The question: "What does ISBE mean for you?" was answered with: scientifically orientated questions (21), scientific explanations (10), real science approach (45), evidence based (25), others (2) (see Figure 3 ). The teachers saw the positive features of ISBE as motivation for students (37), learn how to do real research (29), self-determination (32), methods not facts (13), others (2) (see Figure 0).

\section{Discussion}

In our study, science motivation of science teachers not surprisingly scored very high; especially the intrinsic motivation did. All motivation sub-scales showed high scores ((intrinsic motivation (IM), self-efficacy (SE), self-determination (SD), career motivation (CM) and grade motivation (GM)). As Bandura (1977) had pointed to the need for self-efficacy for reaching a goal, our teachers showed high self-efficacy beliefs for science education. Defined as "people's beliefs about their capabilities to produce effects" (Bandura, 1994, p.71), self-efficacy is largely the perception of someone's action's impact. And it is the best predictor of motivation and success in learning science. Zimmerman (2000) specified it as the basis for achievement resources depending of what the self-efficacy beliefs should measure. Bandura (1997) described high self-efficacy beliefs as more effective in challenging a task and work consistently, as harder and with greater persistence.

Deci \& Ryan (1985) had described self-determination as differentiating types of motivation, distinguishing between intrinsic and extrinsic motivation: intrinsic motivation is doing something with an inherent will, and extrinsic motivation has to do with goal oriented actions driven by external circumstances for 
example grade motivation. The first may exist in every human, but the latter may not (Ryan \& Deci, 2000). However, as intrinsic and extrinsic motivation belong together, our teacher's sample showed high scores in intrinsic and extrinsic motivation for science as well as in self-determination. The career motivation is also very high, without surprise, as teachers already have chosen a career. Teachers often show high interest and motivation scores in the STEM sector as for instance Marth \& Bogner (2018) or Schmid \& Bogner (2015) have shown.

The technology interest and the social aspects of technology showed the same trend as the science motivation: teachers who are participate in the summer school are highly interested in technology and also have high scores in social aspects of technology. This is unfortunately not the same in public view; there is even the contrary present a decrease of technology and science motivation (George, 2006). This trend is at least a little bit referred to teachers, because they often show no preferences for technology, especially primary school teachers (Mc Robbie, 2000). This fact may prevent the introduction of new technologies and applications of technologies in the school context. This is in line with Stein, Ginns, \& McDonald (2006), who have detected many difficulties in real classrooms when teaching technology.

The social aspects of technology describes that society is dependent on technology, because more and more new technologies come into the lives of teachers and students (Bouras \& Albe, 2008). For that reason it is important that there is a continuous exchange between scientists and technology teachers (Stein et al., 2006). In the summer school many physics teachers are participating, so the scores of the technology questionnaire are very high probably because of that fact. Technology preferences should be transferred from the highly interested teachers to the school context and so to students and the public.

Distinction in science motivation before and after summer school participation in our study is not significant. It could be possible, that we have a ceiling effect in our measurement, because all participants were extremely motivated for science even before summer school participation. It is possible, that only the most motivated teachers participated in their free time in a voluntary summer school. In student summer schools we could often see an increase in science motivation and interest as Gibson \& Chase (2002) have shown for a two week inquiry-based summer science program (which raised positive attitudes towards science and also showed more motivation and interest in scientific topics). Students of academically lower high schools often showed a lower splashdown effect, when they come in school again (Stake \& Mares, 2005): Less motivated and interested person showed a higher effect as higher motivated, because when they are already promoted before you couldn't see an effect after such program participation. That could be also a fact in our summer school, the teachers are already highly motivated and you couldn't see a splashdown effect, because a ceiling effect gilded the program effect. 
Summer schools are not only attractive and useful for school students, also college students showed positive influences in motivation and interest after participating science summer camps (Knox et al., 2003). A summer institute in America was established at the beginning of new courses, which improves the university science teaching enormously (Pfund et al., 2009). Also, the teacher could increase their attitudes and skills like problem-based learning in science summer camps, as well as parents, get to know college opportunities for their children (Sterling et al., 2007).

The motivation sub-scales correlate with each other, that's in line with Glynn et al. (2011) as well as the technology sub-scales do, which is also shown by Marth \& Bogner (2017). Relationships between technology and science seem complex: Science motivation with its sub-scales self-efficacy and career motivation intervene with an interest in technology as well as with the social aspects of technology. Similarly, Obrentz (2012) or have reported such dependencies with other variables such as achievement. Schumm \& Bogner (2016) reported even a relationship with personality measures. This motivation seems to provide a major influence in a technology driven interventions (e.g., Mistler-jackson \& Songer 2000; Girwidz, Rubitzko; Pöhnl \& Bogner 2012). Comparably, the general ideas and beliefs of scientists show a big influence on the motivation and the interest in technology and science. Technology and Science are belonging in the today's world together and presupposes each other. Because of this reason, teachers need to combine these fields in order to enrich students' motivation and beliefs about the scientific understanding and also to build up new cognitive structures supporting scientific literacy and technological know-how.

In our case, gender did not produce differences neither in science motivation nor in interest in technology. Such a lack is shown in many other studies: Zeyer (2010), for example, reported such in motivation for learning science, while Marth \& Bogner (2017) did this for upper secondary school students. However, most of the literature described gender differences in the science and technology sector for the youngest children up to adults and even for teacher samples: Male participants often show higher science motivation scores than female counterparts (Obrentz, 2012; Glynn et al., 2011). Schumm \& Bogner (2016) also reported lower self-efficacy science scores for 10th graders, Obrentz (2012) showed the same trend for freshman or (Marth \& Bogner, 2018) for teachers in interest in technology scores.

Generally, the STEM sector is under represented by women (Dasgupta \& Stout, 2014), even in the labor market woman are in the minority (Beede, Julian, \& Langdon, 2011). Often female models lack the science sector, as girls do not have someone supporting them adequately (Dasgupta \& Stout, 2014). Not to forget women often need to combine family and work (Stout, Dasgupta, Hunsinger, \& McManus, 2011). Rennie \& Jarvis (1995) showed gender differences in the technology sector along whole school careers. Marth \& Bogner (2018) showed also gender differences in technology interest in three different age groups, namely students, freshmen and in service teachers. 
Male participants always showed more technology interest and social aspects of technology instead of the social aspects of the teachers group, they are gender balanced. Although most of the literature indicated gender differences in the science sector, our study showed that the gender differences are could be conquered with motivation and interest, because in the summer school with highly motivated participants, we have no gender gap between male and female participants. A possibility to overcome the gender gap could be an inquiry learning approach. Schmid \& Bogner (2015), for example were able to report a narrowing the gender gap within an IBSE approach.

IBSE insertion has shown positive effects, as $65.8 \%$ have used IBSE already before participation. That is an amazing score as it assures that the constructivism view of learning has reached schools like pedagogic and science researchers repeatedly had recommended (Osborne \& Dillon, 2008). Consequently, a summer school program needs just to refresh IBSE, as $60.5 \%$ after participation is even more motivated to use it in school contexts. Nearly all participants saw the IBSE approach as meaningful and useful in their daily teacher's life as they also did to value the real science approach as well as to place scientifically orientated questions. This is of high value as even short-time inquiry interventions have shown positive effects in motivation and knowledge acquisition (e.g., Gerstner \& Bogner, 2010, Schmid \& Bogner, 2015). Von Secker \& Lissitz (1999) described that teacher-guided learning scenarios are often negatively associated with science achievement: The freer the more successful for students are in inquiry science approaches. The inquiry is regarded a good possibility to raise the science motivation and the technology interest especially girls (e.g., Goldschmidt \& Bogner, 2016) and that is why IBSE needs inclusion in the teaching daily routine. It may promote science interest and motivation even in younger ages as thus may motivate more young people to choose academic STEM careers (as the summer school teachers had done).

\section{Future Research \& Limitations of the study}

There must be a future research especially in the field of teachers summer schools, because this sector is up to date very rare reviewed. More teachers have to be interviewed to get more information as with standard questionnaires with pre-assembled answer possibilities. This could be a chance to get much more detailed information of the teachers, who are participating the summer schools. Based on that, it is possible to overcome the biggest limitation of our study, namely the ceiling effect. When you collect quantitative as well as qualitative data of the teacher you can overcome that effect. Another limitation of the study was the low participant number. This number of 67 participants has to be enlarged in future studies to get a bigger explanatory power.

\section{Conclusion}

Monitoring science motivation and technology interest will not yet solve the problem of low aspiration in the STEM sector. However, when participating teachers are highly motivated and interested in science as well as in technology by furthermore using new methods like IBSE approaches in the classroom, a spill over to students seems likely. Teachers will very likely share their own 
fascination with kids. Especially teachers are the triggers to overcome lacks of motivation and interest in the STEM sector. As summer schools make the teacher aware of new approaches in STEM education (e.g., Fröhlich, Sellmann, \& Bogner, 2013, Schmid \& Bogner 2015, Marth \& Bogner, 2017a) that they can even better trigger their students to accept and acknowledge STEM. Additionally, summer schools refresh and introduce new and innovative learning approaches for teachers which especially in science as the fastest growing subject is of major interest. Summers schools can add another important drop to support the STEM - and to transfer fascination to the young ones admitting careers to the STEM.

\section{Conflict of interest}

The authors declare that they have no conflict of interest.

The Permission Note has been received to use any material in the manuscript such as figures, etc. which is not original content.

\section{Acknowledgements}

This work was supported by the European HORIZON-2020 framework labeled CREATIONS: Developing an Engaging Science Classroom (Grant Agreement No.665917; http://creations-project.eu), Stories (Grant Agreement No. 731872) as well as ISE (Inspiring Science Education) project funded by the European Commission (CIP-ICT-PSP-2012-325123). Any opinions, findings, conclusions or recommendations expressed in this material are those of the authors and do not necessarily reflect the position of the founding institutions. We would like to thank all teachers who supported our study.

\section{References}

Ardies, J., De Maeyer, S., \& David Gijbels. (2013). Reconstructing the Pupils Attitude Towards Technology-survey. Design and Technology Education: An International Journal, 18(2006), 8-19.

Ardies, J., De Maeyer, S., Gijbels, D., \& van Keulen, H. (2015). Students attitudes towards technology. International Journal of Technology and Design Education, 25(1), 43-65. http:/ / doi.org/10.1007/s10798-014-9268-x

Bandura, A. (1977). Toward a unifying theory of behavioral change. Psychological Review, 84(2), 191-215. http:// doi.org/10.1037/0033-295X.84.2.191

Bandura, A. (1994). Self-Efficacy. Encyclopedia of Human Behavio, 4, 71-81. http://doi.org/10.1002/9780470479216.corpsy0836

Bandura, A. (1997). Self-efficacy: The Exercise of Control. Encyclopedia of Human Behavior, 4, 71-81. http://doi.org/10.1002/9780470479216.corpsy0836

Beede, D., Julian, T., \& Langdon, D. (2011). Women in STEM: A Gender Gap to Innovation. U.S. Department of Commerce, Economics and Statistics Administration, 1-11. http://doi.org/10.2139/ssrn.1964782

Blanchard, M. R., Southerland, S. A., Osborne, J. W., Sampson, V. D., Annetta, L. A., \& Granger, E. M. (2010). Is inquiry possible in light of accountability?: A Quantitative comparison of the relative effectiveness of guided inquiry and verification laboratory instruction. Science Education, 94(4), 577-616. http://doi.org/10.1002/sce.20390

Bouras, A., \& Albe, V. (2008). Viewpoints of higher education teachers about technologies. International Journal of Technology and Design Education, 18(3), 285305. http://doi.org/10.1007/s10798-007-9027-3 
Cakir, M. (2008). Constructivist Approaches to Learning in Science and Their Implications for Science Pedagogy: A Literature Review. International Journal of Environmental \& Science Education, 3(4), 193-206.

Colburn, A. (2000). An Inquiry Primer. Science Scope, 23(6), 42-44. Retrieved from http://0-

search.ebscohost.com.umaclib3.umac.mo/login.aspx?direct=true\&db=eric\&AN $=$ EJ612058\&site $=$ eds-live

Dabney, K. P., Tai, R. H., Almarode, J. T., Miller-Friedmann, J. L., Sonnert, G., Sadler, P. M., \& Hazari, Z. (2012). Out-of-School Time Science Activities and Their Association with Career Interest in STEM. International Journal of Science Education, Part B, 2(1), 63-79. http://doi.org/10.1080/21548455.2011.629455

Dasgupta, N., \& Stout, J. G. (2014). Girls and Women in Science, Technology, Engineering, and Mathematics: STEMing the Tide and Broadening Participation in STEM Careers. Policy Insights from the Behavioral and Brain Sciences, 1(1), 21-29. http:// doi.org/10.1177/2372732214549471

DeBoer, G. E. (2000). Scientific Literacy: Another Look at Its Historical and Contemporary Meanings and Its Relationship to Science Education Reform. Journal of Research in Science Teaching, 37(6), 582-601. http://doi.org/10.1002/1098-2736(200008)37

Deci, E. L., \& Ryan, R. M. (1985). Intrinsic motivation and self-determination in human behavior. Journal of Chemical Information and Modeling (Vol. 53). http://doi.org/10.1017/CBO9781107415324.004

Ernest, P. (1989). The Knowledge, Beliefs and Attitudes of the Mathematics Teacher: a model. Journal of Education for Teaching, 15(1), 13-33. http:// doi.org/10.1080/0260747890150102

Feldman, K. A. (1976). The superior college teacher from the students' view. Research in Higher Education, 5(3), 243-288. http://doi.org/10.1007/BF00991967

Fröhlich, G., Sellmann, D., \& Bogner, F. X. (2013). The influence of situational emotions on the intention for sustainable consumer behaviour in a student-centred intervention. Environmental Education Research, 19(6), 747-764. http://doi.org/10.1080/13504622.2012.749977

Frome, P. M., Alfeld, C. J., Eccles, J. S., \& Barber, B. L. (2006). Why don't they want a male-dominated job? An investigation of young women who changed their occupational aspirations. Educational Research and Evaluation, 12(4), 359-372. http://doi.org/10.1080/13803610600765786

George, R. (2006). A Cross -domain Analysis of Change in Students' Attitudes toward Science and Attitudes about the Utility of Science. International Journal of Science Education, 28(6), 571-589. http:// doi.org/10.1080/09500690500338755

Gerstner, S., \& Bogner, F. X. (2010). Cognitive Achievement and Motivation in Hands-on and Teacher-Centred Science Classes: Does an additional hands-on consolidation phase (concept mapping) optimise cognitive learning at work stations? International Journal of Science Education, 32(7), 849-870. http://doi.org/10.1080/09500690902803604

Gibson, H. L., \& Chase, C. (2002). Longitudinal Impact of an Inquiry-Based Science Program on Middle School Students' Attitudes Toward Science. Science Education, 86(5), 693-705. http://doi.org/10.1002/sce.10039

Girwidz, R., Rubitzko, T., Schaal, S., \& Bogner, F. X. (2006). Theoretical Concepts for Using Multimedia in Sience Education, 17(2), 77-93.

Glynn, S. M., Brickman, P., Armstrong, N., \& Taasoobshirazi, G. (2011). Science motivation questionnaire II: Validation with science majors and nonscience majors. Journal of Research in Science Teaching, 48(10), 1159-1176. http:// doi.org/10.1002/tea.20442 
Glynn, S. M., Taasoobshirazi, G., \& Brickman, P. (2009). Science motivation questionnaire: Construct validation with nonscience majors. Journal of Research in Science Teaching, 46(2), 127-146. http:// doi.org/10.1002/tea.20267

Goldschmidt, M., \& Bogner, F. X. (2016). Learning About Genetic Engineering in an Outreach Laboratory: Influence of Motivation and Gender on Students' Cognitive Achievement. International Journal of Science Education, Part B, 6(2), 122. http:// doi.org/10.1080/21548455.2015.1031293

Institute ISB. (2004). Curriculum 6th grade. Retrieved from https://www.isb.bayern.de/gymnasium/lehrplan/gymnasium/fachprofilebene-2/natur-und-technik-/325/

Kleinginna, P. R., \& Kleinginna, A. M. (1981). A categorized list of motivation definitions, with a suggestion for a consensual definition. Motivation and Emotion, 5(3), 263-291. http://doi.org/10.1007/BF00993889

Knox, K. L., Moynihan, J. A., \& Markowitz, D. G. (2003). Evaluation of Short-Term Impact of a High School Summer Science Program on Students' Perceived Knowledge and Skills. Journal of Science Education and Technology, 12(4), 471-478. http://doi.org/10.1023/B:JOST.0000006306.97336.c5

Laugksch, R. (2000). Scientific literacy: A conceptual overview. Science Education, 84, 7194. http://doi.org/10.1002/(SICI)1098-237X(200001)84:1<71::AIDSCE6 $>3.0 . \mathrm{CO} ; 2-\mathrm{C}$

Markowitz, D. G. (2004). Evaluation of the Long-Term Impact of a University High School Summer Science Program on Students ' Interest and Perceived Abilities in Science. Science Education, 13(3), 395-407. http://doi.org/10.1023/B:JOST.0000045467.67907.7b

Marth, M., \& Bogner, F. X. (2017a). Does the issue of bionics within a student-centered module generate long-term knowledge? Studies in Educational Evaluation, 55(September), 117-124. http:// doi.org/10.1016/j.stueduc.2017.09.001

Marth, M., \& Bogner, F. X. (2017b). How a Hands-on BIONICS Lesson May Intervene with Science Motivation and Technology Interest. International Journal of Learning, Teaching and Educational Research, 16(5), 72-89.

Marth, M., \& Bogner, F. X. (2018). Monitoring a gender gap in interest and social aspects of technology in different age groups. International Journal of Technology and Design Education. http://doi.org/10.1007/s10798-018-9447-2

Mc Robbie, J. C. ; (2000). Preservice primary teachers\&\#039; thinking about technology and technology education. International Journal of Technology and Design Education, 10(d), 81-101.

Miller, J. D. (1983). Scientific Literacy: A Conceptual and Empirical Review. Daedalus (Boston), 112(2), 29-48. Retrieved from http://www.jstor.org/stable/20024852

Minner, D. D., Levy, A. J., \& Century, J. (2010). Inquiry-based science instruction - what is it and does it matter? Results from a research synthesis years 1984 to 2002. Journal of Research in Science Teaching, 47(4), 474-496. http://doi.org/10.1002/tea.20347

Mishra, P., \& Koehler, M. J. (2006). Technological Pedagogical Content Knowledge: A Framework for Integrating Technology in Teacher Knowledge. Teachers College Record, 108(6), 1017-1054. http:// doi.org/10.1111/j.1467-9620.2006.00684.x

Mistler-jackson, M., \& Songer, N. B. (2000). Student Motivation and Internet Technology: Are Students Empowered to Learn Science? Journal of Research in Science Teaching, 37(5), 459-479.

O'Keeffe, G. S., \& Clarke-Pearson, K. (2011). The Impact of Social Media on Children, Adolescents, and Families. PEDIATRICS, 127(4), 800-804. http://doi.org/10.1542/peds.2011-0054 
Obrentz, S. (2012). Predictors of Science Success: The Impact of Motivation and Learning Strategies on College Chemistry Performance. Educational Psychology and Special Education Dissertations.

Osborne, J., \& Dillon, J. (2008). Science Education in Europe: Critical Reflections A Report to the Nuffield Foundation, (January), 32.

Pfund, C., Miller, S., Brenner, K., Bruns, P., Chang, a., Ebert-May, D., ... Handelsman, J. (2009). Summer Institute to Improve University Science Teaching. Science, 324(5926), 470-471. http:// doi.org/10.1126/science.1170015

Pintrich, P. R., \& De Groot, E. V. (1990). Motivational and Self-Regulated Learning Components of Classroom Academic Performance. Journal of Educational Psychology, 82(1), 33-40. http:// doi.org/10.1037/0022-0663.82.1.33

Pöhnl, S., \& Bogner, F. X. (2012). Learning with Computer-Based Multimedia: Gender Effects on Efficiency. Journal of Educational Computing Research, 47(4), 387-407. http://doi.org/10.2190/EC.47.4.c

Rennie, L. J., \& Jarvis, T. (1995). English and Australian Children's Perceptions about Technology. Research in Science \& Technological Education, 13(1), 37-52. http://doi.org/10.1080/0263514950130104

Rocard, M., Csermely, P., Jorde, D., Lenzen, D., Walberg-Henriksson, H., \& Hemmo, V. (2007). Science Education NOW: A Renewed Pedagogy for the Future of Europe. RTD Info, 29. http:/ / doi.org/ISBN 978-92-79-05659-8

Russ, R. S., Scherr, R. E., Hammer, D., \& Mikeska, J. (2008). Recognizing mechanistic reasoning in student scientific inquiry: A framework for discourse analysis developed from philosophy of science. Science Education, 92(3), 499-525. http://doi.org/10.1002/sce.20264

Ryan, R., \& Deci, E. (2000). Self-determination theory and the facilitation of intrinsic motivation. American Psychologist, 55(1), 68-78. http://doi.org/10.1037/0003066X.55.1.68

Schmid, S., \& Bogner, F. X. (2015). Does inquiry-learning support long-term retention of knowledge? International Journal of Learning, Teaching and Educational Research, 10(4), 51-70.

Schumm, M. F., \& Bogner, F. X. (2016). Measuring adolescent science motivation. International Journal of Science Education, 38(3), 434-449. http://doi.org/10.1080/09500693.2016.1147659

Schwab, J. J., \& Brandwein, P. F. (1962). The teaching of science as enquiry. The Teaching of Science, 3-103. Retrieved from http:// hal.archives-ouvertes.fr/hal-00692064

Stake, J. E., \& Mares, K. R. (2005). Evaluating the impact of science-enrichment programs on adolescents' science motivation and confidence: The splashdown effect. Journal of Research in Science Teaching, 42(4), 359-375. http://doi.org/10.1002/tea.20052

Steele, J., James, J. B., \& Barnett, R. C. (2002). Learning in a Man'S World: Examining the Perceptions of Undergraduate Women in Male-Dominated Academic Areas. Psychology of Women Quarterly, 26(1), 46-50. http://doi.org/10.1111/14716402.00042

Stein, S. J., Ginns, I. S., \& McDonald, C. V. (2006). Teachers learning about technology and technology education: Insights from a professional development experience. International Journal of Technology and Design Education, 17(2), 179-195. http://doi.org/10.1007/s10798-006-0008-8

Sterling, D. R., Matkins, J. J., \& Frazier, W. M. (2007). Science Camp as a Transformative Experience for Students, Parents, and Teachers in the Urban Setting. School Science \& Mathematics, 107(4), 134-148. http://doi.org/10.1111/j.19498594.2007.tb17928.x

Stout, J. G., Dasgupta, N., Hunsinger, M., \& McManus, M. a. (2011). STEMing the tide: using ingroup experts to inoculate women's self-concept in science, technology, 
engineering, and mathematics (STEM). Journal of Personality and Social Psychology, 100(2), 255-270. http://doi.org/10.1037/a0021385

Tamir, P. (1985). Content analysis focusing on inquiry. Journal of Curriculum Studies, 17(1), 87-94. http:// doi.org/10.1080/0022027850170107

Ülkü-Steiner, B., Kurtz-Costes, B., \& Kinlaw, C. R. (2000). Doctoral student experiences in gender-balanced and male-dominated graduate programs. Journal of Educational Psychology, 92(2), 296-307. http://doi.org/10.1037/00220663.92.2.296

Von Secker, C. E., \& Lissitz, R. W. (1999). Estimating the impact of instructional practices on student achievement in science. Journal of Research in Science Teaching, 36(10), 1110-1126. Retrieved from http://www.scopus.com/inward/record.url?eid=2s2.0-0040882947\&partnerID $=40 \& m d 5=6 \mathrm{~d} 8 \mathrm{bd} 3 f 85 \mathrm{ddd} 22 \mathrm{e} 94 \mathrm{a} 883 \mathrm{de} 95 \mathrm{~b} 4 \mathrm{f} 719 \mathrm{~d}$

Zeyer, A. (2010). Motivation to Learn Science and Cognitive Style. Eurasia Journal of Mathematics Science \& Technology Education, 6(2), 121-128.

Zimmerman, B. J. (2000). Self-efficacy: An essential motive to learn. Contemporary Educational Psychology, 25(March), 82-91. http://doi.org/10.1006/ceps.1999.1016 